\title{
Hypercalcaemia due to immobilization of a patient with Paget's disease of bone
}

\author{
A. W. NATHAN* \\ M.B., M.R.C.P. \\ D. W. WILSON \\ M.B., F.R.C.S.
}

\author{
H. A. LUDLAM \\ M.B. \\ P. DANDONA \\ D.Phil., M.R.C.P.
}

The Royal Free Hospital, Pond Street, London NW3 2QG

\begin{abstract}
Summary
A man with Paget's disease of bone was admitted with a fractured neck of femur. On admission he was normocalcaemic, but with immobilization he rapidly became hypercalcaemic, despite a normal diet and no medication. The hypercalcaemia responded to calcitonin. Although hypercalcaemia is often quoted as complicating the immobilization of such patients, well documented uncomplicated cases have rarely been reported.
\end{abstract}

\section{Introduction}

Although textbooks (for example, Duthrie and McCormick, 1977) often refer to hypercalcaemia secondary to the immobilization of patients with Paget's disease, this phenomenon has in fact only rarely been reported (Reifenstein and Albright, 1944; Fuss, Bergans and Corvilain, 1978; Auld, Simpson and Smyth, 1979). Previously reported cases have been complicated by excessive calcium or vitamin D intake, by hyperparathyroidism (Kohn and Myerson, 1961) or by the absence of pre-immobilization control biochemistry. We report a patient with well documented hypercalcaemia developing only after immobilization and apparently uncomplicated by other factors.

\section{Case report}

A 76-year-old man was admitted after falling and sustaining an intertrochanteric extracapsular fracture of the neck of his left femur. He had a 10-year history of Paget's disease of bone, with typical radiological features of bone lysis and sclerosis. He was an active man who ate a normal diet and took no medication. Following the fall, a Denham pin was inserted, and a

\footnotetext{
*Present address: Department of Cardiology, St Bartholomew's Hospital, West Smithfield, London EClA 7BE.
}

splint was applied, but the patient remained bedbound for a total of 12 weeks.

Despite normal biochemistry on admission (including a serum calcium of $2.54 \mathrm{mmol} /$ litre), after 11 days the serum calcium concentration had risen to 2.7 $\mathrm{mmol} /$ litre and the urine calcium excretion rose from 5.3 to $16.3 \mathrm{mmol} / 24 \mathrm{hr}$. After a further rise in the serum calcium to $2.86 \mathrm{mmol} / \mathrm{litre}$, subcutaneous salmon calcitonin at a daily dose of $50 \mathrm{MRC}$ units was started. As can be seen from Figure 1 there was rapid normalization of the serum calcium concentration. The urine calcium excretion was measured after $2 \frac{1}{2}$ weeks, by which time it had fallen to the control value. These changes, together with the fall in serum alkaline phosphatase levels, are detailed in Figure 1. Renal function remained normal throughout (plasma urea $5.6 \mathrm{mmol} /$ litre) as did the serum albumin level $(39 \mathrm{~g} /$ /itre $)$. The serum parathyroid hormone $(0 \cdot 2$ $\mathrm{ng} /$ litre) and $25-\mathrm{OH}$ vitamin D (12.4 $\mu \mathrm{g} /$ litre) levels, measured at the time of admission, were also normal.

\section{Discussion}

Serum calcium and phosphate concentrations are usually normal in patients with Paget's disease. However, hypercalcaemia has been described in a number of cases. The majority have been in association with hyperparathyroidism (Kohn and Myerson, 1961), but several cases of hypercalcaemia following immobilization have been recorded. In the first report by Reifenstein and Albright (1944) two patients are described, both with long-standing Paget's disease and recent fractures of the femur. However, one of these patients drank excessive quantities of milk, and the other was taking a vitamin D preparation. Fuss et al. (1978) reported an alcoholic man with Paget's disease, who was found to be hypercalcaemic after lying in coma for some time. Pre-coma biochemistry was not available. Auld et al. (1979) reported the most recently described case, but their patient had taken large quantities of calcium gluconate for many 


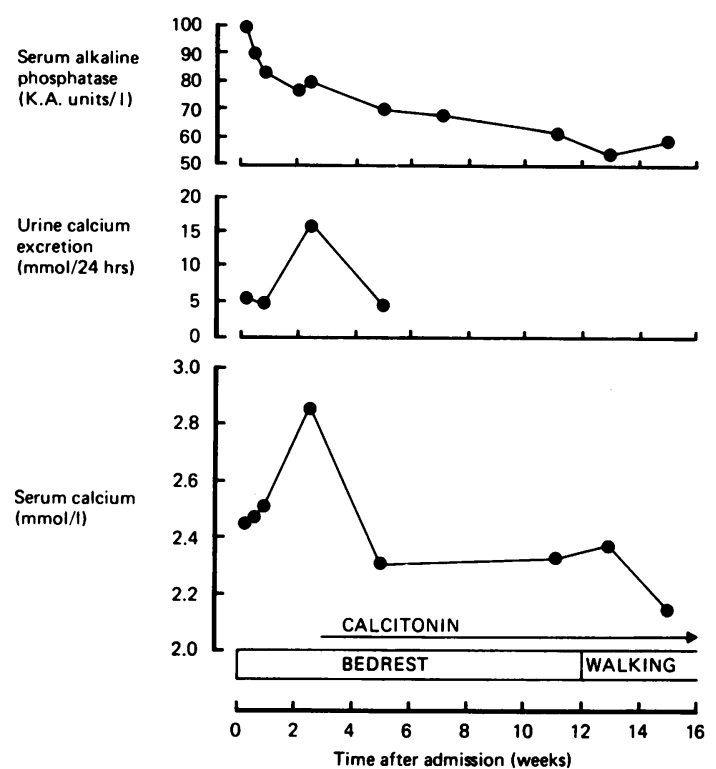

Fig. 1. Biochemistry, ambulatory state and drug therapy from the time of admission until discharge.

years. In addition, Nagant de Deuxchaisnes and Krane (1964) have reported hypercalciuria in uncomplicated cases of Paget's disease following fractures not accompanied by immobilization.

The patient reported here had a normal dietary intake of calcium and vitamin $D$, and normal biochemistry on admission (before prolonged immobilization) including vitamin $D$ and parathyroid hormone levels. Both the serum calcium concentration, and the urine calcium excretion rose with bedrest, and the serum alkaline phosphatase fell, supporting the theory of decreased osteoblastosis and constant osteoclastosis following both the fracture and the immobilization. The patient responded rapidly to calcitonin (Evans, 1979).

Although based on relatively complicated cases, the original observations of Reifenstein and Albright are supported by this more straightforward case.

\section{References}

Auld, W.H.R., Simpson, R.H. \& SMYTH, M. (1979) Hypercalcaemia in Paget's disease of bone. Lancet, i, 562.

DUTHRIE, J.J.R. \& MCCORMICK, J.N. (1977) Diseases of connective tissues, joints and bones. In: Davidson's Principles and Practice of Medicine, (Ed by Macleod, J.) 12th edition, p. 655. Churchill Livingstone, Edinburgh.

EvanS, I.M.A. (1979) Calcitonin treatment of Paget's disease. Lancet, ii, 1232.

FUSS, M., Bergans, A. \& CoRvilain, J. (1978) Hypercalcaemia due to immobilisation in Paget's disease of bone. Lancet, if, 941.

KOHN, N.N. \& MYERSON, R.M. (1961) Hyperparathyroidism associated with Paget's disease. Annals of Internal Medicine, 54, 985.

Nagant de Deuxchaisnes, C. \& Krane, S.M. (1964) Paget's disease of bone: clinical and metabolic observations. Medicine (Baltimore), 43, 233.

Reifenstein, E.C. \& Albright, F. (1944) Paget's disease: its pathologic physiology and the importance of this in the complications arising from fracture and immobilization. New England Journal of Medicine, 231, 343. 